\title{
Research on the Teaching Content System of Clothing Design and Engineering in Practice
}

\author{
Juan $\mathrm{Li}^{1, \mathrm{a}}$ \\ ${ }^{1}$ Zhengzhou Institute of Industrial Technology, Nanyang, Henan, 451100 \\ a email
}

Keywords: Fashion Design and Engineering, Practice Teaching; Innovation Ability

\begin{abstract}
Practice teaching has an important role in higher education clothing. Based on the current situation of professional practice and teaching oriented education culture assays clothing design and engineering, from the aspects such as clothing design and engineering disciplines characteristics and teaching objectives, costume design and engineering practical teaching system construction and implementation to start, build and innovative ability to adapt to the target multi-level modular fashion design and engineering experiment teaching new system to improve the efficiency of teaching and learning experiment, cultivate abilities of students, industry adaptability and innovation, entrepreneurship.
\end{abstract}

\section{Introduction}

Practice teaching colleges train high-quality talent is an indispensable element. Relative theoretical teaching, it has greater potential and advantages in cultivating students' innovative and practical ability to improve their overall quality. Today, China's garment industry to take off, is struggling clothing Calls the Development of education, society and culture better Chinese garment industry, the application of qualified, skilled, complex, senior technical personnel clothing, clothing professional educators priority [1]. In recent years, carried out in clothing design and engineering practical teaching system reform, adhere to adapt its mission of industrial development, to determine the training objectives based on industry background and social needs, according to the training objectives set practical teaching content to determine teaching methods, the formation of a sets of unique practical teaching system for enterprises train outstanding fashion professionals to achieve seamless integration of production with teaching provides a strong guarantee [2].

\section{Disadvantages of Fashion Design and Engineering Practice Teaching Training oriented education}

Universities are now widely used in clothing mainly oriented education, quality education, supplemented by training model, which has shown the gap between the needs of society and. Adjustment of education objectives, content, evaluation system, management system, attention to the role of education in the integration of research activities, the transition examination-oriented education to quality education, innovation and education to achieve the establishment of a new mode of talent cultivation practice, is the need for education reform the need, the need for social progress and economic development.

\section{Costume Design and Engineering Disciplines Teaching Objectives}

Fashion design and engineering disciplines features. Fashion Design and Engineering is an artistic creation and industrial production cross-disciplinary education is the ability requires highly professional, in addition to their teaching work in line with general education colleges clothing requirements, but also reflect the art and in Engineering - education, that highlight the practical teaching.

Teaching objectives. Costume design and engineering training to adapt to social and economic 
development needs, moral, intellectual, physical development, master costume design and engineering basic theory and basic knowledge, with costume design, clothing technology, clothing production and management capabilities to in the apparel industry or garment manufacturers and other related departments, engaged in garment design, clothing technology and design, clothing production and management work of high-quality applied talents.

Practical teaching objectives. Fashion Design and Engineering Practice majors students apparel product design and production technology ability to develop scientific literacy, innovation and teamwork spirit, to provide students with a theory and practice of effective channels. For students of clothing design, clothing production, process management have a certain perceptual knowledge, so that the combination of theory and practice better, into practice and to promote students' digestion of knowledge, deepen understanding of the theory, and can Fostering students' ability to analyze and solve problems, enable students to use the system apparel production technology to solve problems costume design, clothing technology and design, production management and other clothing encountered for students ready to go to work as soon as possible.

\section{Example Construction and Fashion Design and Engineering Practice Teaching Content}

General education content system. General Education (General Education) comes from the ancient Greek philosopher Aristotle Liberal Education (Liberal Education) thinking, originated in Europe, formed in the United States. The introduction of general education, will help to broaden the students 'knowledge structure, strengthen students' humanistic spirit, they will develop into a comprehensive quality innovative talents. An important feature of general education is to break the barriers of traditional disciplines to achieve Mutual Infiltration Arts and intermediation, which broaden the students' knowledge of the professional structure, breaking the limitations of existing training model undoubtedly has a strong targeted. Fashion Design and Engineering Practice Teaching Content System in general education is provided with military training, professional social practice, foreign language proficiency comprehensive exam, Computer Application, Computer Application other courses, so that students have basic military skills social cognition, foreign languages, computer use and other skills. General education can effectively gives students a strong sense of mission and broad-minded, they will develop into healthy, happy, perfect personalities, which they will in the future create positive healthy excellent work to lay a good foundation.

Construction rofessional education practical teaching system. Professional education is the core of fashion design and engineering practice teaching, teaching content of each module progressively, step by step, a ring set a ring, a layer progressive form a strong chain, to provide a favorable flexibility for teachers, students space, thereby forming a new teaching model envisaged [3]. The basic theory and professional knowledge, practical mastery of the new operating system, highlighting the relationship between classroom teaching and social practice, the practice of clear training direction system settings market relations.

Fashion Design and Construction of Teaching Content System Engineering chain to focus on solving the basic training courses and professional practice course disjointed, practical courses and Comprehensive Practice Class disjointed, integrated product design course and practice course disjointed series of problems. In this regard, costume design and engineering practice of the teaching profession must change the traditional mode of teaching, strengthen the close combination of theory and practice teaching courses, the "basic professional skills training - Professional training comprehensive ability-professional scientific research ability training" three stages Practice teaching is essential. Professional training in basic skills, the basic training courses introducing professional practice course; comprehensive ability in professional training, the professional practice course introducing comprehensive practice course; professional training in research capability, will imported products of the Practical Course design course.

Practical teaching content practical teaching mode. Costume design and engineering undergraduate practical teaching can be divided into professional basic training and comprehensive, innovative design of the training, for the two levels of training. Costume design and engineering undergraduate training base platform includes drawings, clothing color design, costume renderings, 
computer renderings clothing, clothing basic technology, textile materials science, clothing CAD, clothing production Course and many other practical training courses. Learning Through the above Training Course to equip students with costume design, clothing technology and other infrastructure application capabilities. Costume design is for apparel applications design, and core apparel product development, fashion design, costume design for applications exist, so costume design technology students must master skills to students of digital production knowledge, thereby adapt to the market economy on clothing professional practitioners of modern, high standards.

Professional basic training in the basic course training mainly focused on solving the students theory and practice, to promote the use of knowledge and practical ability to improve the problem, students professional skills and basic initial comprehensive ability. Costume design and engineering undergraduate comprehensive, innovative training platform includes designing clothing structure and process (a), clothing structure and process (b), garment pattern design, draping clothing, fashion design, garment production technology management, clothing design and technology curriculum design, plate making industry and technology curriculum design, graduate design (thesis), professional social practice, innovation and education and many other practical training courses. Comprehensive and innovative design of the training courses are core courses costume design and engineering undergraduate teaching. By learning more training courses to equip students with clothing design, clothing technology and design, clothing production and management capability to meet the requirements of costume design and engineering undergraduate training objectives. Fashion Design and Engineering is an integrated multi-disciplinary, multi-course, for the professional practice course system constructed more courses to complete each train capacity. Comprehensive and innovative design of the courses and training to professional courses and related courses integrated design-oriented, focused on solving the problem of professional and technical proficiency of training and training research, innovative learning ability, so that students have an initial capacity of research .

Innovative Education System. Costume design and engineering is a combination of technology and art disciplines, in personnel training, pay attention to guide students to independent learning, innovative capacity. Ability focuses on the integrated application ability and innovation ability to combine, for which you can set up vocational skills certification and training courses in various competitions. Occupational Skill Testing is a student and a professional comprehensive ability test rating, but also for the students 'employment ready; competitions training exercise can express students' creative thinking, the finalists and winners of the competition students also provided a broad space for development. In addition, we need to set up academic lecture courses, organizing social practice and ideological education activities. On the basis of study courses on offer more elective course at the same time, in order to provide students with a deep development. For learning good students, founded the clothing brand design studio, will they be absorbed into the actual project work and course binding while organizing students to participate in school level and above professional related innovative fashion design contest and system board division contest, students formed preliminary research ability and strong ability to innovate.

Practice teaching management and quality assurance system. College, department established practice of instructional leadership team, responsible for the entire macro-management practice teaching. Practice teaching organization and implementation responsibility to the people, the implementation of management by objectives. Integrated practice production practice and other arrangements sufficient specific guidance under a trainee teacher content. College teaching quality supervision practice run, the implementation of practical teaching programs, coordination of oversight responsibility for the operation of reports submitted to the Leading Group for Teaching hospital practice after practice teaching. Through a series of evaluation system to examine the quality of practice teaching, including student evaluation, expert evaluation, peer evaluation. To ensure the quality of teaching, teaching committee set up to establish reward system for teachers, bad teachers student evaluation process to be closed. Training course selection for the doors is once a year, selected and discharged excellent course, and as a declaration of colonel, provincial, national quality class of the basic conditions. 
Practical Teaching System Condition. Strengthening the practice and training young teachers to improve practical skills and the ability to solve practical problems in production, employment off-campus practice base strong technology and experienced technical staff working part-time teachers. In school training base, training tasks bear costume, complete garment production and processing operations internship. Adhere to open education, social services, serving the purpose of the local economy, the close relationship between schools and enterprises to establish a solid base for off-campus internships, classroom teaching and social break with the practice, and separated from the workshop situation, to establish a solid base for teaching practice (research training base) [4].

\section{Conclusion}

With the reform and changes in the employment situation of college graduates market economy, costume design and engineering practical teaching system can be constructed in terms of the number of personnel training, quality and knowledge structure and the changing socio-economic adapt and achieve teach seamless production. Adhere to the development of industry to adapt its mission, according to the needs of society and industry background to determine the training objectives, training objectives set in accordance with the practice of teaching content, form a unique practical teaching system. The system disciplines intersect, highlighting the practical skills, has become the development trend of clothing science and technology teaching. Therefore, students of clothing design and engineering of the training, it must have a solid foundation and the basic theory and knowledge of the apparel production management, highlighting their practical skills in order to meet the social needs of the production as soon as possible after graduation. Therefore, personnel must practice cultivation to modern skills, practical, complex transformation from the traditional knowledge-based, expertise type. Guidelines, training objectives, course structure, practical teaching system, but also should focus on how to improve students' practical ability and work hard.

\section{References}

[1] Zou Ping. On the apparel industry and culture professionals [J]. Chinese Vocational and Technical Education, 2004,12: 14-16.

[2] Wu Xiaobing, Zou Ping. Costume design talents to teach seamless production [J]. Chinese textile economy, 2004,12 (4): 56-58.

[3] Zou Ping. clothing chain structure design curriculum model [J]. textile education, 2006, 149 (6): 35-38.

[4] Gao Haisheng, Kang Weimin, Zhang Xin. universities "Food Science and Engineering" New Practice Teaching System [J]. Hebei Normal University (Social Science Edition), 2006,5 (1): 24-26. 